\title{
Isolation, Cultural and Morphological Characterization of Phomopsis vexans (Sacc. and Syd.) Harter, causing Stem Blight and Fruit Rot of Brinjal
}

\author{
M. R. Thesiya ", K. B. Rakholiya and R. Lokesh \\ Department of Plant Pathology, N. M. College of Agriculture, Navsari Agricultural \\ University, Navsari, Gujarat 396 450, India \\ *Corresponding author
}

\section{A B S T R A C T}

\begin{tabular}{|c|}
\hline Keywords \\
\hline $\begin{array}{l}\text { Phomopsis vexans, } \\
\text { brinjal, Stem blight } \\
\text { and fruit rot, } \\
\text { Pathogenicity, } \\
\text { Cultural } \\
\text { characteristics, } \\
\text { Morphological } \\
\text { characteristics }\end{array}$ \\
\hline Article Info \\
\hline $\begin{array}{l}\text { Accepted: } \\
22 \text { June } 2020 \\
\text { Available Online: } \\
10 \text { July } 2020\end{array}$ \\
\hline
\end{tabular}

\section{Introduction}

The brinjal (Solanuum melongena L.) is "King of Vegetables" also known as aubergine or eggplant from the plant family Solanaceae is an important vegetable crop grown in India as well as in other parts of the world. India is considered to be the center of origin of cultivated brinjal and grown throughout the year. The major brinjal growing countries are China, India, United state, Egypt, Indonesia, Japan and Turkey.
Phomopsis vexans affected stem and fruit of brinjal crop collected from the field and isolated on potato dextrose agar (PDA) produced white cottony growth, sub-aerial mycelial, circular shaped colony with indistinct zonation and good sporulation. Pigmentation is yellow to dark brown colour. Pycnidia formation takes place after 18 to 20 days which are dark brown in colour and scattered distribution on the media surface. Morphological characteristics of Phomopsis vexans revealed hyaline, septate mycelium which measures 2.9 to $3.7 \mu \mathrm{m}$ in diameter. The alpha conidia which were one celled, hyaline and subcylindrical to elliptical were measuring $8.1 \mu \mathrm{m}$ (length) x $2.2 \mu \mathrm{m}$ (width) on stem and $7.5 \mu \mathrm{m}$ (length) x $3.5 \mu \mathrm{m}$ (width) on fruit. Pycnidia produced on host surface (87.2-283.0 $\mu$ x 90-303 $\mu$ ) and on cultural medium (58.49-381.49 $\mu$ x 79.3- $439 \mu)$. 
contains $0.3,1.4$ and $0.3 \mathrm{~g}$ of fats, proteins and minerals, respectively, per $100 \mathrm{~g}$ of fruit pulp (Choudhury, 1967). In addition to vegetables, the fruit is also used as a cure for toothache and liver disorders. Brinjal roots and stems are used in traditional preparations for the treatment of rheumatism, asthma and heart disease. Brinjal is also considered as a common home remedy for Type 2 diabetes (Anonymous, 2009). Diseases are one of the major limiting factors for low productivity in this crop. The major diseases affecting this crop are stem blight and fruit rot [Phomopsis vexans (Sacc. and Syd.) Harter], damping off [Pythium aphanidermatum (Eds.) Fitz.], collar rot [Sclerotium rolfsii Sacc.], bacterial wilt [Pseudomonas solanacearum E.F.Smith], alternaria leaf spot [Alternaria melongenae Rangs and Samb, A. solani (Ell. and Mart.)], root knot [Meloidogyne javanica (Treub) Chitwood, M. incognita Kofoid and White] and little leaf (Phytoplasma) (Rangaswami and Mahadevan, 2005 and Singh, 2018). Among them, stem blight and fruit rot is considered to be the most destructive disease of brinjal (Singh, 1999). It is considered to be the most serious and widespread disease in most of the tropical and sub-tropical areas. Stem blight and fruit rot incited by Phomopsis vexans. It was first reported in Italy (Spegazzini, 1881) and in India, it was reported from Bombay in 1935 by Uppal et al., (1935).

Symptoms of disease are exhibited by all the foliar plant part viz., leaves, stem, branches, fruit stock and fruit. However, the disease is more prominent on leaves during the early stages of plant growth showing circular to irregular greyish brown spots. On the stem, the disease develops in the form of elongated, blackish-brown lesion and stem and branches are dried. Initial symptoms on fruits appeared as small, pulpy, yellow-brown sunken lesions, variable in size and shape. Sometimes they are surrounded by a dark brown margin.
Lesions later increase in size, develop yellowish to brown concentric ring which bears black, erumpent pycnidia. The fruit area around the lesion becomes hard. Such fruits in advance stages dry out shriveled (Schwartz and Gent, 2007). Stem blight and fruit rot commonly occurring disease in brinjal growing area ranks second only to bacterial wilt in destructiveness. It is destructive in subtropical and tropical regions where 50 percent loss has been recorded (Pandey et al., 2002).

\section{Materials and Methods}

\section{Disease samples}

\section{Collection of diseased sample}

Naturally infected brinjal cv. GNRB-1, GJLB-4 and Surati Ravaiya showing typical disease symptoms of stem and fruit blight were collected from Vegetable Research Station, N.A.U., Navsari. Diseased specimens brought to the laboratory and examined under the microscope for preliminary examination of pathogen and later on, the samples were used for isolation of the pathogen.

\section{Isolation of fungal pathogen}

The infected tissues were taken and cut into small bits with the help of a sterilized blade. Bits of diseased tissues were surface sterilized with 0.1 percent mercuric chloride solution for 30 seconds followed by three washing with sterilized distilled water in sterilized Petri plates. The surface sterilized bits were then placed directly on the surface of potato dextrose agar (PDA) in Petri plates under aseptic conditions and incubated at $27 \pm 1^{\circ} \mathrm{C}$ temperature. Typical fungal growth developed around the bits. Microscopic observations of fungal culture revealed septate hyphae. The pure culture of the fungus was received by the hyphal tip method. 


\section{Culture media}

Potato dextrose agar (PDA) (Dhingra \& Sinclair, 1995) medium was used for obtaining pure cultures of fungi used in experiments. The ingredient of semi-synthetic media used was as follows.

\begin{tabular}{|l|l|}
\hline Potatoes (Peeled and Sliced) & $\mathbf{: 2 0 0} \mathbf{g}$ \\
\hline Dextrose (Anhydrous) & $: 20 \mathrm{~g}$ \\
\hline Agar-agar & $: 20 \mathrm{~g}$ \\
\hline Distilled water & $: 1000 \mathrm{ml}$ \\
\hline
\end{tabular}

\section{Identification of pathogen}

The pathogens were tentatively identified through microscopic study of pure cultures through cultural and morphological characteristics. Morphological characteristics of the fungal structures were studied in cotton blue stained slides under the compound microscope. Microscopic observations of pycnidia and conidia were made at magnification of $10 \mathrm{X}$ and $40 \mathrm{X}$. The cultures were further confirmed and identified with comparing to earlier literature. The microphotograph was also taken. Cultures were maintained on PDA slants by subculturing and stored at $5{ }^{\circ} \mathrm{C}$ for further study.

\section{Pathogenicity test}

\section{Raising Seeding for Pathogenicity}

Pathogenicity tests were performed with susceptible and widely grown brinjal cultivar GNRB-1 and Surati Ravaiya to prove the Koch's postulates. Seedlings were transplanted in pots containing sterilized soil. One seedling per pot was maintained and kept in net house.

\section{Stem inoculation}

Stem inoculation was made by toothbrush injury in which the first injury was made with carborandom powder on the stem then sterilized toothbrush dipped in the spore suspension and inoculated with gentle rubbing on the stem at 3 to 4 places. Toothbrush injury with inoculation of sterilized distilled water served as a check. The inoculated area was covered with sterilized non-absorbent cotton to avoid contamination and provide moisture. Observations on disease expression were recorded for up to eight days.

\section{Fruit inoculation}

Fruit inoculation was made by a pinpricking method in which a sterilized pin was used to prick the fruit and inoculum $(0.2 \mathrm{ml})$ applied with sterilized cotton swab. Suitable controls with only pinprick was maintained. The inoculated and check fruits were kept for disease development. Disease symptoms and pycnidial formation were recorded. Three replications were kept in all the inoculation methods. On potted brinjal plants which after 10 days were show symptoms resembling those seen in nature.

\section{Cultural characteristics of the pathogen}

Twenty $\mathrm{ml}$ sterilized media was poured in sterilized Petri plates. Five mm disc of fungal growth was cut from 10 days old culture grown on PDA. After incubation for 10 days, radial growth was measured. The colony characters such as colony type, pigmentation, zonation, sporulation and pycnidial density etc. were also recorded simultaneously.

Morphological characteristics of the pathogen

To study morphology including shape and size of conidia as well as the presence of guttulae (oil drops) in the conidia of isolate fungus, pure cultures were grown on PDA. After 20 days, the conidia were mounted in cotton blue lactophenol and measured 
microscopically at $40 \mathrm{X}$ using ocular and stage micrometer. The observations were recorded in three repetitions.

\section{Results and Discussion}

\section{Visual observations}

Stem blight and fruit rot diseased specimens of carrot crop collected from fields exhibited typical symptoms as: On the Stem, the disease developed in the form of, blackish-brown elongated lesion and later minute black pycnidia developed in the center of old lesions. Initial symptoms on fruits appeared as small, pulpy, yellow-brown sunken lesions surrounded by yellowish to brown concentric ring with black, erumpent pycnidia. Infected fruits were black, soft and mummified.
Finally, the diseased fruits were shriveled and dried. On the splitting of severely infected fruit, pulp and seeds were also found black and rotted. Similar type symptoms of stem blight and fruit rot caused by Phomopsis vexans were observed earlier by Singh (2018), Rangaswami and Mahadevan (2005), Jayaramaiah et al., (2013) Mahadevakumar and Janardhana (2016).

\section{Isolation of fungal pathogen}

The pathogen causing stem blight and fruit rot of brinjal was isolated from the naturally infected stem and fruits. The culture was isolated by the tissue isolation technique, which yielded the pure culture of $P$. vexans. This was maintained on PDA for further investigations.

Table.1 Pathogenicity of $P$. vexans on brinjal stem/fruits under in vivo conditions

\begin{tabular}{|c|l|c|c|c|}
\hline $\begin{array}{c}\text { Sr. } \\
\text { No. }\end{array}$ & \multicolumn{1}{|l|}{ Inoculation method } & $\begin{array}{c}\text { Inoculated } \\
\text { stem/fruit }\end{array}$ & $\begin{array}{c}\text { Infected } \\
\text { stem/fruit }\end{array}$ & $\begin{array}{c}\text { Per cent } \\
\text { infection }\end{array}$ \\
\hline $\mathbf{1}$ & Tooth brush injury & 3 & 3 & $\mathbf{1 0 0}$ \\
\hline $\mathbf{2}$ & Pin prick injury & 3 & 3 & $\mathbf{1 0 0}$ \\
\hline $\mathbf{3}$ & $\begin{array}{l}\text { Control } \text { i.e. } \text { without } \\
\text { Inoculation }\end{array}$ & $\mathbf{3}$ & $\mathbf{0}$ & $\mathbf{0 . 0 0}$ \\
\hline
\end{tabular}

Table.2 Colony characteristics of $P$. vexans

\begin{tabular}{|c|l|l|}
\hline Sr. No. & & \multicolumn{2}{|c|}{\begin{tabular}{c} 
Colony characters \\
\hline $\mathbf{1}$
\end{tabular}} & Type & Sub-aerial \\
\hline $\mathbf{2}$ & Colour & Chite cottony growth \\
\hline $\mathbf{3}$ & Shape & Circular \\
\hline $\mathbf{4}$ & Zonation & Indistinct \\
\hline $\mathbf{5}$ & Radial growth & $88.00 \mathrm{~mm}$ \\
\hline $\mathbf{6}$ & Pycnidial distribution & Scattered \\
\hline $\mathbf{7}$ & Pycnidia formation & 18 to 20 days \\
\hline $\mathbf{8}$ & Pycnidia colour & Dark brown colored \\
\hline $\mathbf{9}$ & Sporulation & Good sporulation \\
\hline $\mathbf{1 0}$ & Pigmentation & Yellow to dark brown color \\
\hline $\mathbf{1 1}$ & Growth Rate & Very slow \\
\hline
\end{tabular}




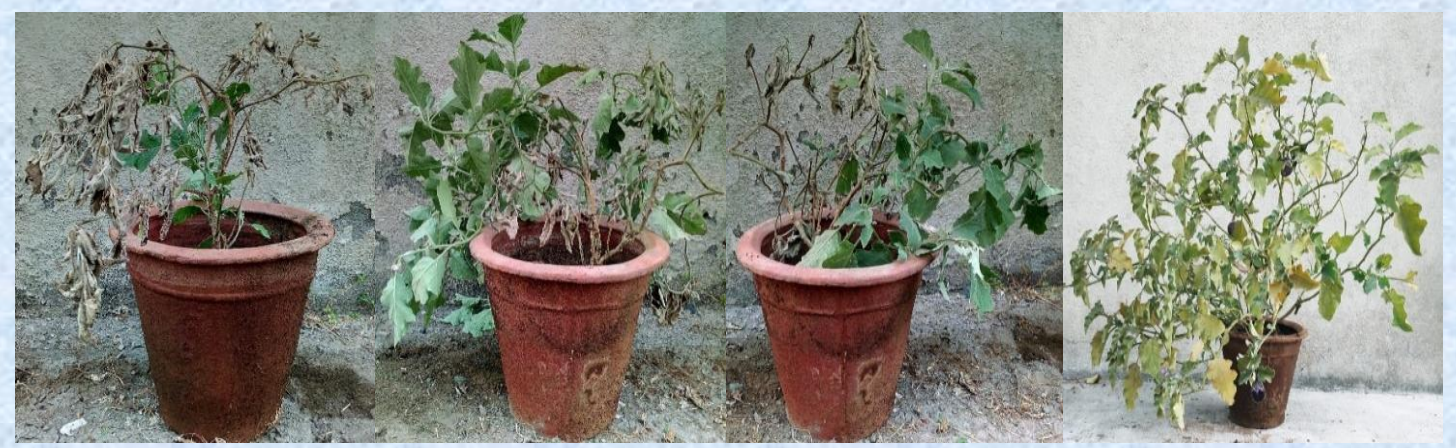

Stem inoculation by tooth brush injury method (inoculated)

\section{Control (uninoculated)}

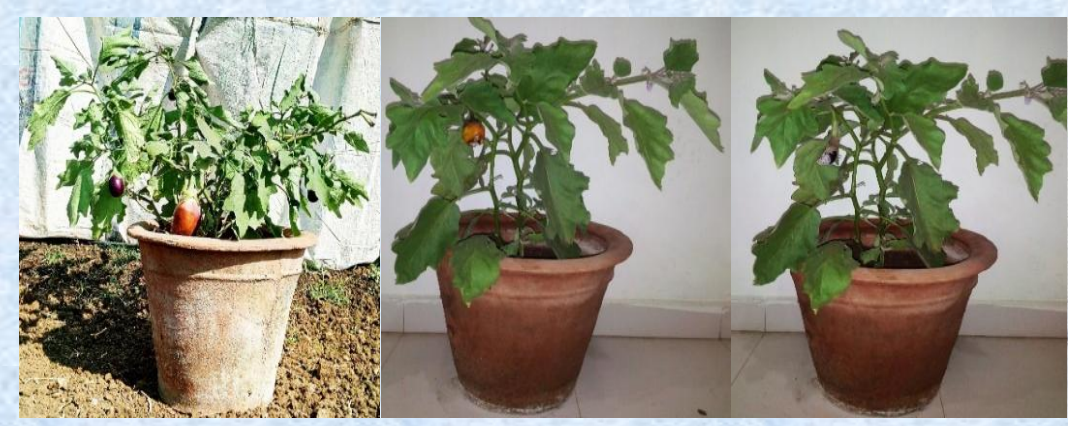

Fruit inoculation by pin-prick method (inoculated)

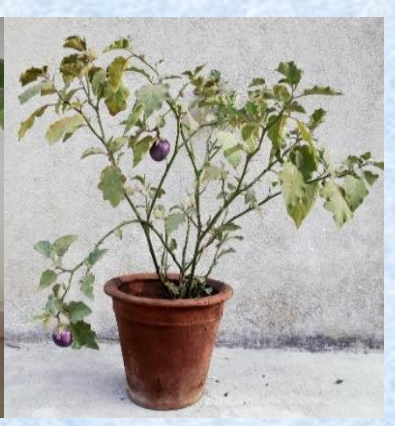

Control (uninoculated)

Plate- 1 : Pathogenicity test of $P$. vexans on stem and fruits showing stem blight and fruit rot symptoms 


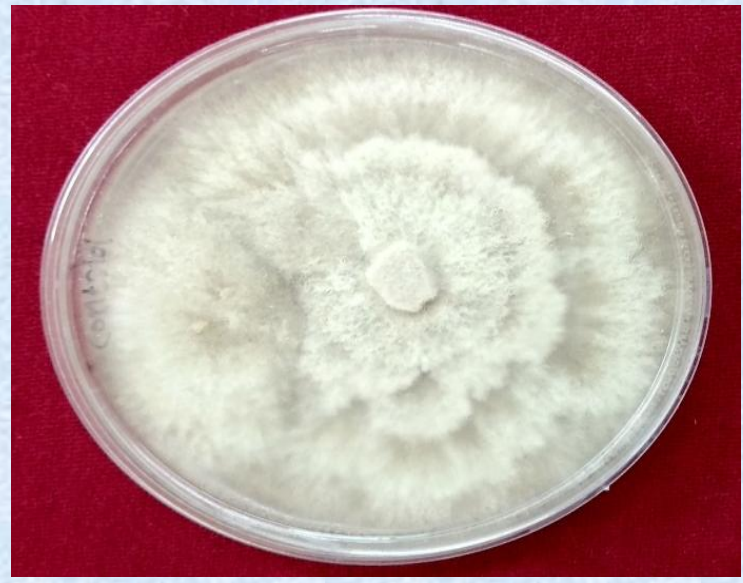

A

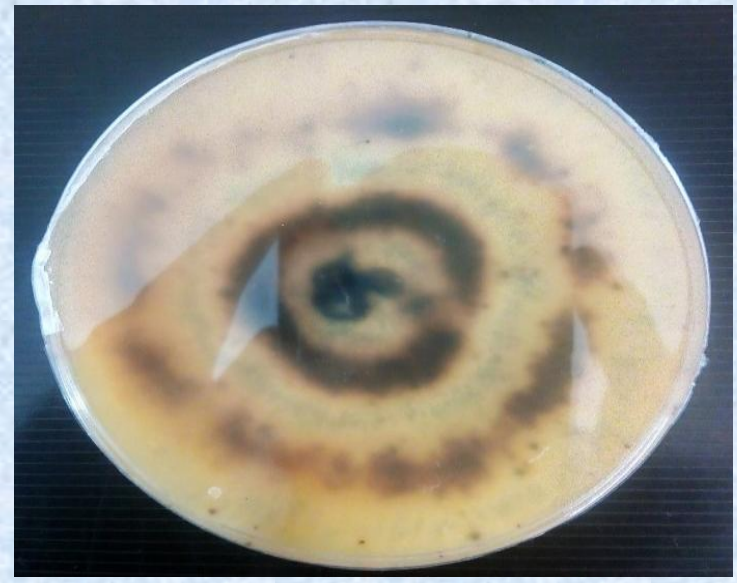

B

C

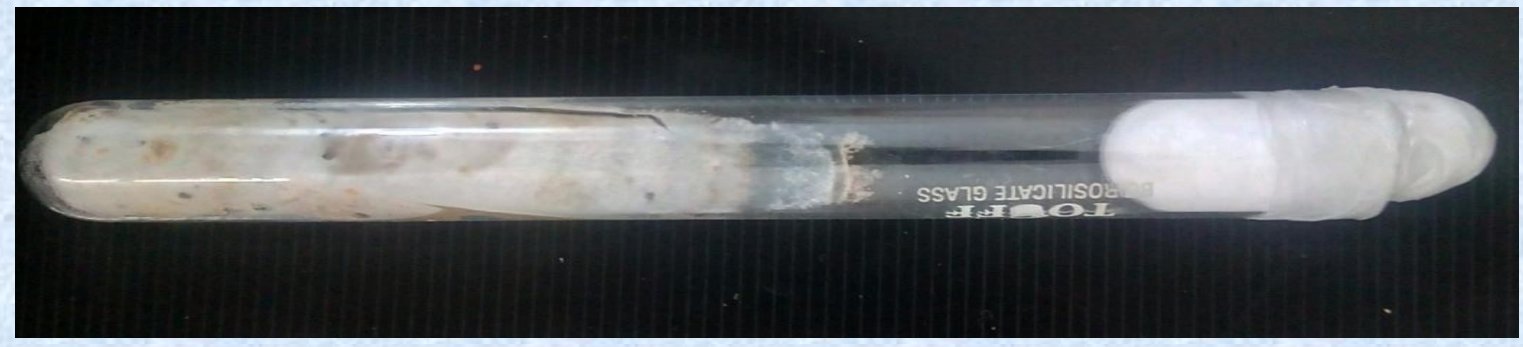

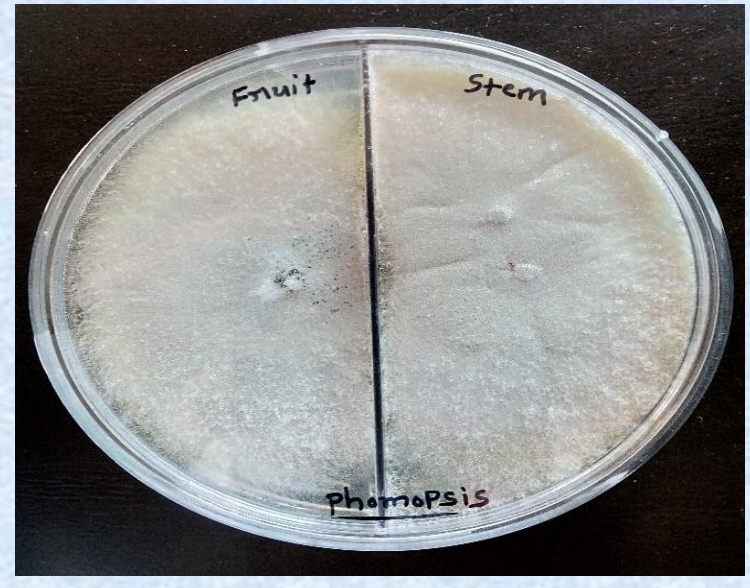

D

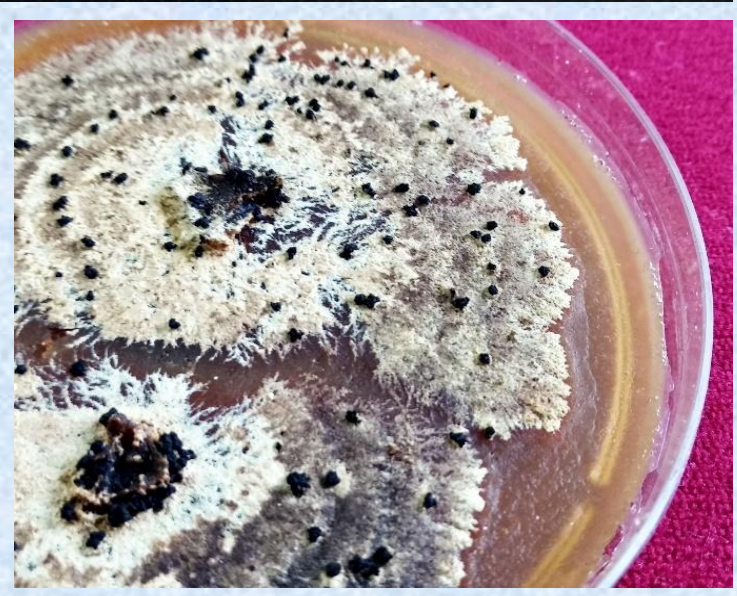

$\mathbf{E}$
A. White cottony growth with indistinct zonation on PDA media
B. Yellow to dark brown colour pigmentation
C. Pure culture of $P$. vexans in slant
D. Pure culture of $P$. vexans isolated from fruit and stem in Petri plate
E. Scattered distribution of dark brown colored pycnidia on PDA media

Plate- 2 : Cultural characteristics of $P$. vexans on PDA 


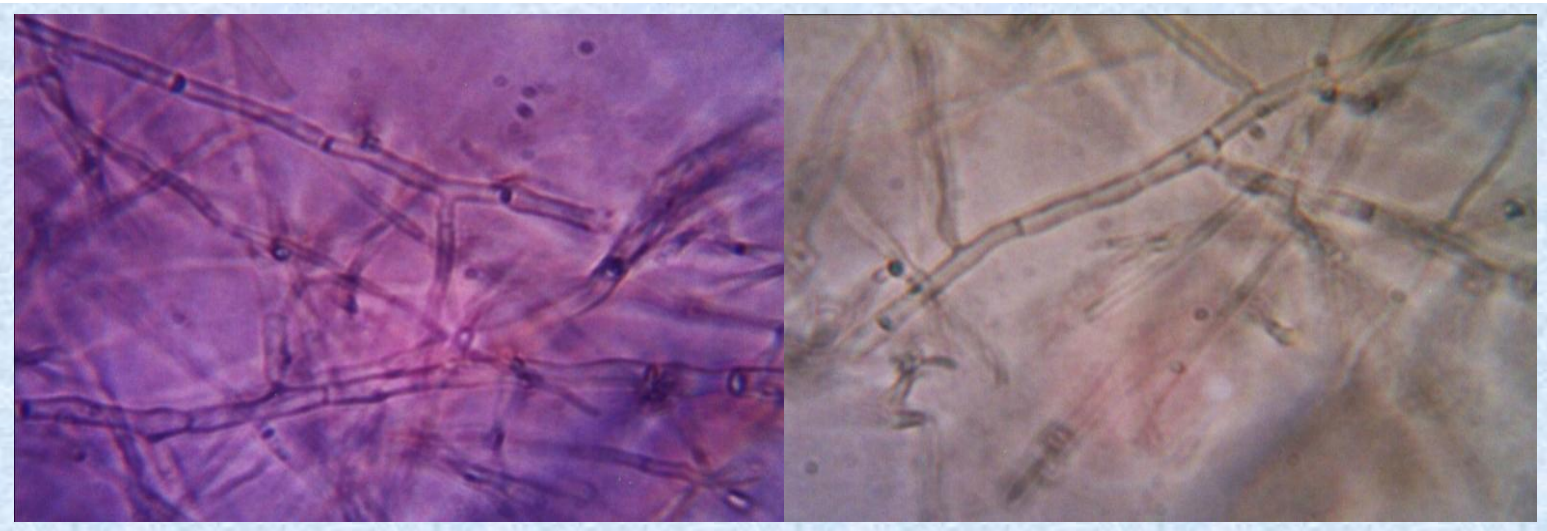

A

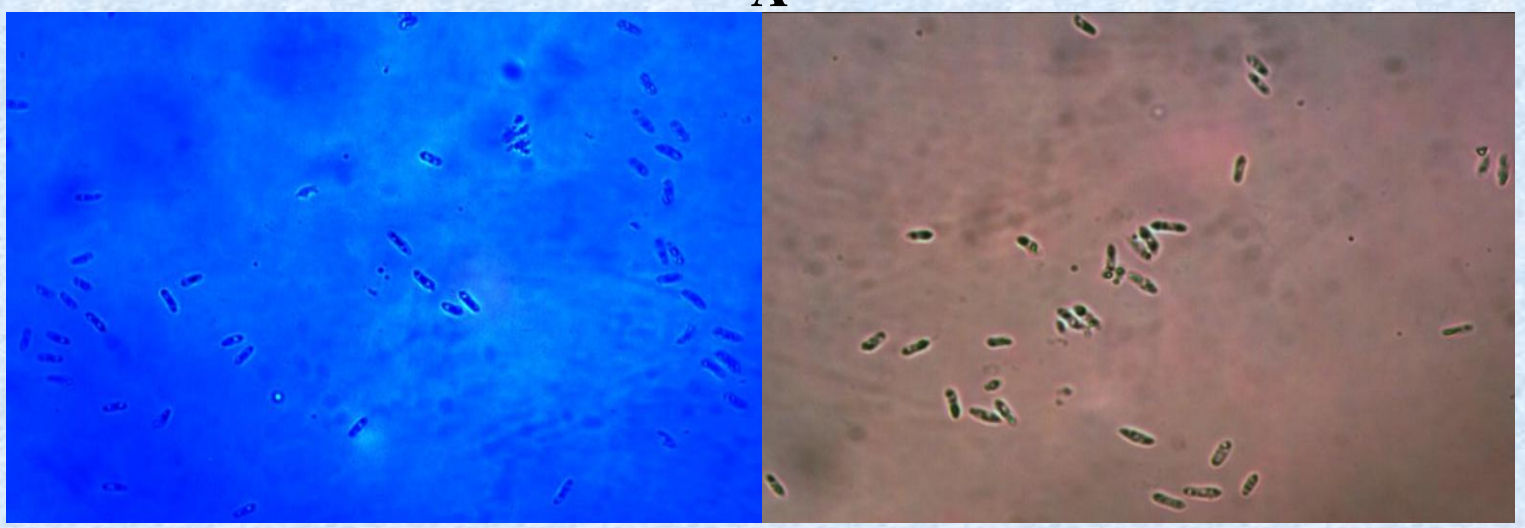

B

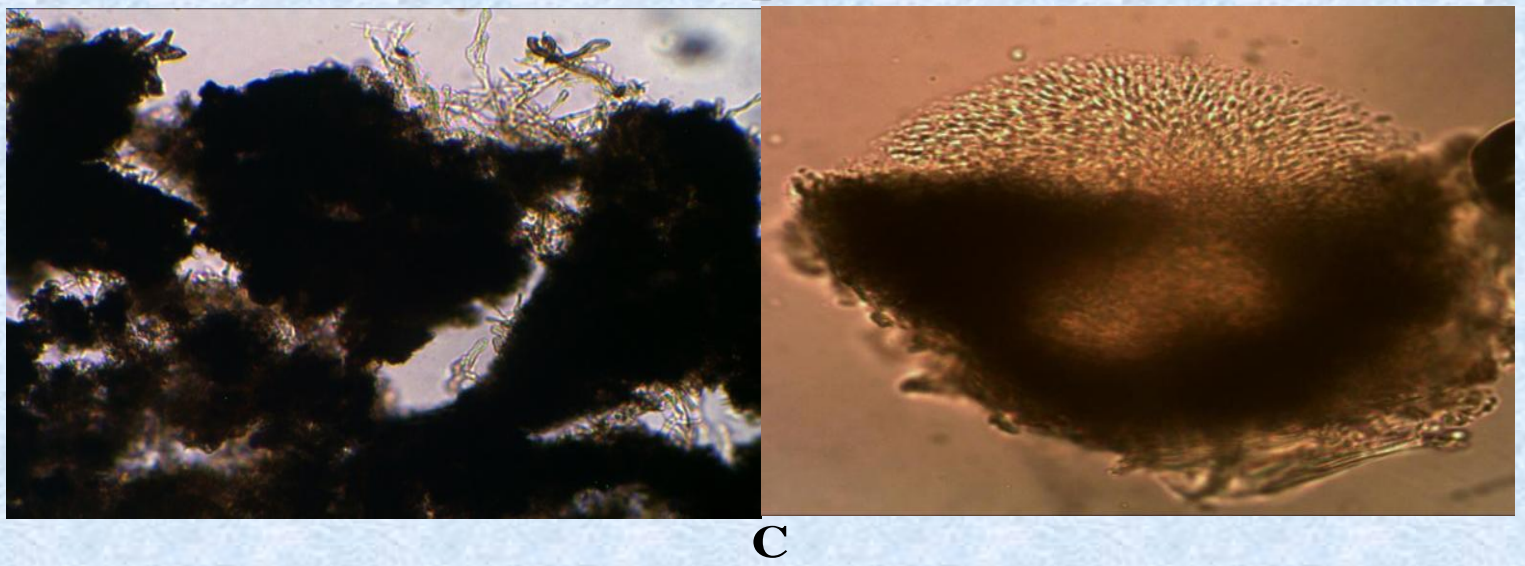

A. Mycelium- Hyaline, septate

B. Alpha conidia - one celled, hyaline and sub cylindrical to elliptical

C. Pycnidia-dark brown colored released pycnidiospores

\section{Plate- 3 : Morphological characteristics of $P$. vexans on PDA}

\section{Identification of pathogen}

The fungal cultures were purified and stored for carrying out further investigations. The hyphal tip of the fungus on PDA was cut and transferred to slants containing PDA. After a sufficient incubation period, the slants were kept in a refrigerator at $50 \mathrm{C}$ and subcultured at regular intervals for maintaining the viability of the pathogen. After purification of 
the fungus were identified based on cultural, morphological and microscopic structure observed under microscope at magnification of $10 \mathrm{X}$ and $40 \mathrm{X}$.

\section{Pathogenicity test}

\section{Stem inoculation}

Stem inoculated with $P$. vexans following toothbrush injury method showed elongated, blackish-brown lesion and later minute dark brown colour pycnidia developed lesions after 7 days of inoculation. Stem and branches dried were observed after 13 days.

\section{Fruit inoculation}

Brinjal fruits inoculated with $P$. vexans following pin-prick method showed small, roughly circular, soft, light yellow lesion surrounded by light brown ring after 6 days of inoculation whereas complete rotting of fruits was observed after 15 days. Mummification of the inoculated fruits was recorded after 20 days of inoculation in the pinprick method. Typical symptoms of stem blight and fruit rot ( $P$. vexans) developed, which were similar to those described by Datar (1980), Lou et al., (2006), Patel (2007) and Pande (2014) who proved pathogenicity of $P$. vexans causing fruit rot with the above methods.

\section{Cultural Characteristics of Pathogen}

The cultural study of $P$. vexans isolate was made by growing single spore culture on solid potato dextrose medium at $27 \pm 2^{\circ} \mathrm{C}$. On potato dextrose agar medium in Petri plates, radial growth $(\mathrm{mm})$ was measured. The colony characters such as, colony type, shape, pigmentation, zonation, sporulation, pycnidia formation and pycnidial density were also recorded.

The cultural characteristics of $P$. vexans recorded in the present study are in the range of description given by Divinagracia (1969) and Akhtar and Chaube (2003).

\section{Morphological Characteristics of Pathogen}

It was seen that alpha conidia which were one celled, hyaline and subcylindrical to elliptical were measuring $8.1 \mu \mathrm{m}$ (length) $\mathrm{x} 2.2 \mu \mathrm{m}$ (Width) on stem and $7.5 \mu \mathrm{m}$ (length) $\mathrm{x} 3.5$ (Width) $\mu \mathrm{m}$ on fruit. Whereas, alpha conidia on the culture medium were slightly bigger in size as $10.0 \mu \mathrm{m}$ (length) x $2.5 \mu \mathrm{m}$ (Width). The variation in size of pycnidia produced on the host surface $(87.2-283.0 \times 90-303 \mu)$ and cultural medium $(58.49-381.49 \mu \quad x \quad 79.3-$ $439 \mu)$. The mycelium consists of hyaline, septate hyphae which measures 2.9 to $3.7 \mu \mathrm{m}$. in diameter. The Beta conidia were not observed throughout the study.

These results are in conformity with the morphological character of $P$. vexans recorded in the present study are in the range of description given by Baldaniya (2000), Akhtar (2009), Mahadevakumar and Janardhana (2016).

\section{References}

Akhtar, J. (2009). Molecular characterization of Phomopsis vexans inciting phomopsis blight and fruit-rot of eggplant. Journal of Mycology and Plant Pathology, 39: 39-41.

Akhtar, J. and Chaube H, S. (2003). Studies on phomoposis blight of brinjal with special reference to variability in Phomopsis vexans, the incitant of the disease. Journal of Mycology and Plant Pathology, 33: 465.

Anonymous (2009). Down to Earth: Online Science and Environment Magazine.

Anonymous (2017). Area and production of horticultural crops in Gujarat state during the year 2016-17. Directorate of Horticulture, Gujarat State, Gandhinagar.

Anonymous (2019). Agricultural Statistics at a Glance. Directorate of Economics and Statistics, Department of Agriculture and Cooperation, Ministry of Agriculture, 
Government of India.

Baldaniya, B. R. (2000). Investigation on stem blight of brinjal (Solanum melongena L.) caused by Phomopsis vexans (Sacc. and Syd.) Harter, M.Sc. (Agri.) Thesis. G.A.U., S.K.Nagar (Unpublished). 60 pp.

Choudhury, B. (1967). Vegetables. National Book Trust, New Delhi. 198 pp.

Datar, V. V. (1980). Brinjal fruit rot caused by Fusarium moniliforme Sheld. A new record from India. Current Science, 49(14): 555.

Dhingra, O. D. and Sinclair, J. B. (1995). Basic Plant Pathology Methods. $2^{\text {nd }}$ Ed. Lewis Publishers, USA. 434 pp.

Divinagracia, G. G. (1969). Some factors affecting pycnidial production of Phomopsis vexans in culture. Philippine Journal of Agriculture, 53: 173 - 184.

Jayaramaiah, K. M., Mahadevakumar, S., Charithraj, A. P. and Janardhana, G. R. (2013). PCR based detection of Phomopsis vexans (Sacc. \& Syd.) - The causative agent of leaf blight and fruit rot disease of brinjal (Solanum melongena L.). International Journal of Life Science, 7(1): $17-20$.

Lou, B. G., Chen, W. J. and Zheng, X. D. (2006). First report of Phomopsis vexans on Ilex crenata thunb. var. convexa in China. Journal of Plant Pathology, 88: 65-70.

Mahadevakumar, S., and Janardhana, G. R. (2016a). Leaf blight and fruit rot disease of brinjal caused by Diaporthe vexans (Phomopsis vexans) in six agro-ecological regions of south West India. Plant Pathology \& Quarantine, 6: 5-12.

Pande, J. K. (2014). Dissecting pathological and bio-chemical changes during brinjal Phomopsis vexans (Sacc. \& Syd.) Harter, interaction. M.Sc. (Agri.) Thesis, N.A.U., Navsari, 20 pp.

Pandey, K. K., Pandey, P. K., Kalloo, G. and Chaurasia, S. N. S. (2002). Phomopsis blight in brinjal and sources of resistance. Indian Phytopathology, 55 (4): 507 - 509.

Patel, D. U. (2007). Investigation on fruit rot [Phomopsis vexans (Sacc. and Syd.) Harter] of brinjal (Solanam melongena L.) and its management under south Gujarat condition. M.Sc. (Agri). Thesis, N.A.U., Navsari, 45 pp.

Rangaswami, G. and Mahadevan, A. (2005). Diseases of crop plants in India. Fourth edition, Prentice. Hall of India pvt. Ltd., New Delhi.

Schwartz, H. F. and Gent, D. H. (2007). Eggplant, pepper and tomato. Phomopsis fruit rot (phomopsis blight). High Plains IPM Guide, a cooperative effort of the University of Wyoming, University of Nebraska, Colorado State University and Montana State University, 1-3 pp.

Singh, D. D. (1999). Survival and management of Phomopsis vexans, the incitant of blight and fruit-rot of brinjal (Solananum melongena L.). M. Sc. (Agri.) Thesis, G. B. Pant Univ. of Agric. \& Tech., Pantnagar, $86 \mathrm{pp}$.

Singh, R. S. (2018). Diseases of vegetable crops. $2^{\text {nd }}$ Edition $(\mathrm{Pb})$. MedTech publisher, New Delhi.

Spegazzini, C. (1881). Nova addend a ad mycologiam. Venetam. Atti Soc. Crittog. Ital., 24: 42-71.

Uppal, B. N., Patel, M. K. and Kamat, M. N. (1935). The fungi of Bombay. Bulletin, 176: 56.

\section{How to cite this article:}

Thesiya, M. R., K. B. Rakholiya and Lokesh, R. 2020. Isolation, Cultural and Morphological Characterization of Phomopsis vexans (Sacc. and Syd.) Harter, causing Stem Blight and Fruit Rot of Brinjal Int.J.Curr.Microbiol.App.Sci. 9(07): 2851-2859.

doi: https://doi.org/10.20546/ijcmas.2020.907.337 